Money for Nothing?

\section{Financing the 2016 and 2020 U.S. Presidential Nomination Campaigns}

\author{
Maciej Turek \\ Jagiellonian University, Poland \\ https://orcid.org/0000-0002-0981-4903
}

Political Preferences

2020, vol. 27: 39-62

journals.us.edu.pl/index.php/PP

Submitted: 03/09/2020

Accepted: $12 / 11 / 2020$

DOI: $10.31261 /$ polpre.2020.27.39-62

\begin{abstract}
:
The aim of the paper is to analyze the relationship between campaign money and winning the 2016 and 2020 presidential nominations in the United States. While in the last two decades of the twentieth century candidates who raised most money almost always became major party nominees, the record is mixed for presidential cycles 2004-2012. By comparing various dimensions of campaign finance, including activities of candidates' campaign committees and outside groups, the Author demonstrates that while successful fundraising, resulting in dozens of millions of dollars at the disposal of candidates, seems necessary to run a competitive campaign, raising the most money is no longer pre-requisite for becoming major party presidential nominee.
\end{abstract}

Keywords: U.S. presidential nominations, campaign finance, money and elections, independent expenditures

\title{
Introduction
}

The legendary American party boss, Mark Hanna, used to say that "there are two things that are important in politics. The first is money and I can't remember what the second one is" (Witcover 1997: 74). Many politicians and office hopefuls seem to agree with that statement, considering ever-increasing amounts of money in American elections. The spending orgy culminates every four years, when Americans elect their president. In the period 2000-2012, expenditures in the presidential election campaigns, including nomination period and general elections, by the 


\section{Maciej Turek}

candidates committees of two major parties alone was \$4,74 billion ${ }^{1}$ (FEC 2016a), and it is generally expected that it will only grow with each electoral cycle.

In this paper, I will focus on the role of money in the Democratic and Republican parties presidential nomination races of 2016 and 2020. Since it is a crucial ingredient of political campaigns in America, it is even more important in the race for presidential nomination. Party reforms in the 1970s, which shifted power over the nomination from party leaders and officials to rank-and-file party supporters, intended to make the whole process more participatory and democratic. It thus required that party organizational structures, at the national and state levels, would restrain from favoring a particular candidate. Without any help from party, the candidates must built their own campaign machines. But more importantly, since the nomination hopefuls are all carrying same party label, "this lowers the range of policy differentiation across candidates for voters to assess (...) and removes major decision cues” (Redlawsk et al. 2011: 142). As a result, "candidates would seek some early circumstance to break loose from pack in public recognition and support" (Witcover 1997: 187). Thus in order to distinguish themselves from their nomination rivals, candidates would seek to disseminate their messages, promote their personalities and emphasize their experience and achievements to gain the voter appeal. And whatever strategy - media, new media or grassroots campaign, or the mixture of all - they choose to execute, it would require considerable amounts of financial resources. In four presidential cycles, from 2000 to 2012, nomination hopefuls' campaign committees spent astonishing $\$ 2,765$ billion (FEC 2016a). The 2000 cycle was the last one when one of major party eventual nominee (Al Gore) was using public funding system to finance his nomination bid. Ever since, the eventual nomination winners declined to use public funds, as it obliged them to spent within the legal limits. Once the campaign advisers developed ways to raise massive amounts from individual donors, presidential candidates stopped to rely on public money, as they have become to be able to raise much more than the government offered, at the same time being not restrained by spending limits.

\section{Research goals}

That better funded candidates usually win is not only a conventional wisdom. William G. Mayer (1996, 2003) found that between 1980 and 2000, the candidates - excluding incumbent presidents

${ }^{1}$ All values throughout the paper are in nominal dollars. 
running for reelection - whose committees raised most money at the end of the pre-election year had become their party nominees each cycle with exception of John Connally in 1980, when Republican nomination was won by Ronald Reagan. ${ }^{2}$ Wayne Steger (2000) corrected the money variable, specifying that amount of money raised as of January 31 of election year would better predict the winning nominee. ${ }^{3}$ However, confronting Steger's finding with subsequent electoral cycles, from 2000 to 2012 some of the early contests were held in January, making his operationalization of the money variable less useful in the longer time frame. Meanwhile, a variable of cash reserves was introduced in the forecasting models, operationalized as either money available on hand (Steger 2000) or "calculated as the percentage of unspent monetary cash reserves available to all campaigns at the end of reporting period" (Adkins \& Dowdle 2005: 652), that is each quarter (Adkins \& Dowdle 2005) or end of December of the year preceding presidential cycle (Steger 2007). While the argument that cash reserves might be more important than money raised - "funds allocated by the campaign in the past have already influenced the voter perception of the candidate. Cash reserves, however, represent unrealized potential for the campaign to affect the candidate's performance in the future" (Adkins \& Dowdle 2005: 651) seems valid, the money variable failed to explain the results of the 2004 and 2008 presidential nominations. Had they worked, the Republican nominee of 2008 would have been Mitt Romney (or Rudy Guliani, if considering cash reserves), not John McCain, and Democratic primaries won by Howard Dean in 2004 and Hillary Clinton in 2008, instead of John Kerry and Barack Obama, respectively. Yet it successfully explained the winner of 2012 Republican Party nomination, as Mitt Romney again had the biggest chest in both money raised and cash reserves, allowing him to become Republican nominee.

The aim of the paper is to examine to what avail have money been important to presidential hopefuls in the 2016 and 2020 nomination campaign, and whether did it help them to become party nominee. Did the money variable fit the Mayer model of 1980-2000, as well as 2012? Or was money not that important, as in 2004 and 2008?

It is worth noticing that eventual winners of the 2016 and 2020 major party nomination races - Hillary Clinton, Donald Trump, and Joe Biden - were (1) established candidates with

${ }^{2}$ To be sure, Mayer also included second variable, candidate standings in the last national Gallup poll before Iowa caucus. The poll variable analysis will be excluded from this analysis.

${ }^{3}$ While this is correct for the period 1980-1996, it is unclear why would Steger move date by a full month, considering that, for instance, 1980 Republican Iowa caucus took place on January 21, when the voting process had already started and might have affected candidate's fundraising. 


\section{Maciej Turek}

broad political connections (Clinton, Biden), which is essential in amassing early money (Goff 2004), (2) were leading the public opinion polls throughout much of the primary campaign before the voting started (Clinton, Trump, Biden), crucial in keeping presidential campaign afloat (Damore 1997), or (3) were personally rich enough to self-fund their presidential bid (Trump). I would therefore hypothesize that $\mathrm{H}_{1}$ Hillary Clinton's, Donald Trump's, and Joe Biden's campaign committees' raised the most money at the end of December of pre-election year. Subsequently, $\mathrm{H}_{2}$ the money model of major party presidential nominations would demonstrate its both explaining and predictive validity for the 2016 and 2020 major party presidential nominations.

In order to address these questions and test the hypotheses, I will compare candidates' committees raising and spending data, available on the Federal Election Commission (FEC) website, in the periods pointed by Mayer (2003). The paper will also investigate the activities of the outside money, mainly the SuperPACs. These entities emerged as a consequences of the Supreme Court ruling in Citizens United v. FEC, and have become an financial arm of political candidates, particularly in the presidential nomination races (Turek 2016). Thus the SuperPAC data shall be included in any analysis related to campaign finance.

\section{6: General Overview}

The 2016 presidential cycle was extraordinary in many respects, including financial activities of the candidates and their campaign committees. Combining two major political parties, there was a record of twenty-two nomination aspirants, 5 in the Democratic Party race and 17 running for the GOP nomination. The extensive pool of candidates was clearly determined by the context of the race - an open election, which always attracts more than one candidate for nomination in both parties. In turn, it may better motivate larger pools of donors to open their pockets than in an incumbent election. Yet remarkably, the 2016 nomination cycle was not the most expensive primary period to date. As Figure 1 clearly indicates, the 2008 primary season stood as a record of financial activities until the 2020 cycle. It can be accounted for the number of competitive candidates in the Democratic Party nomination campaigns. In both 2016 and 2008 we had two major candidates - Hillary Clinton and Bernie Sanders, and Hillary Clinton and Barack Obama, respectively, each raising more than \$200 million (Green \& Kingsbury 2011: 93; Green 2019: 139). Yet in the case of 2008 nomination, only two candidates raised and therefore also spent less 
than Martin O'Malley, who came third in the 2016 Democratic Party race (Green \& Kingsbury 2011: 93).

When it comes to the Republican contests, in nominal dollars GOP nomination hopefuls of 2016 raised slightly more than in 2008, while spending somewhat less than eight years before. But after adjusting for inflation, there was actually more money at candidates disposition than in 2016. Interestingly, in 2016 there were 17 candidates (11 in 2008), out of which eight raised and spent more than 10 million (Green 2019: 139), comparing with six reaching that amount in 2008 (Green \& Kingsbury 2011: 93). Partial explanation might be the extensive use of the SuperPACs, entities present in American political campaigns since 2010, which might solicit and spend unlimited amounts of money on behalf of the candidates as long as they do not coordinate strategy and message with them. In 2016, the Republican candidate's principal committees spent $\$ 377,1$ million in the nomination period (FEC 2016b), while SuperPAC spending was only $\$ 10$ million lower (Malbin \& Glavin 2018: 29). While it is hardly possible all the money would go directly to the candidates' organizations had SuperPACs been non-existent, certainly part of it would be at the disposal of campaign committees.

Figure 1: Principal Campaign Committees Totals, 2000-2020

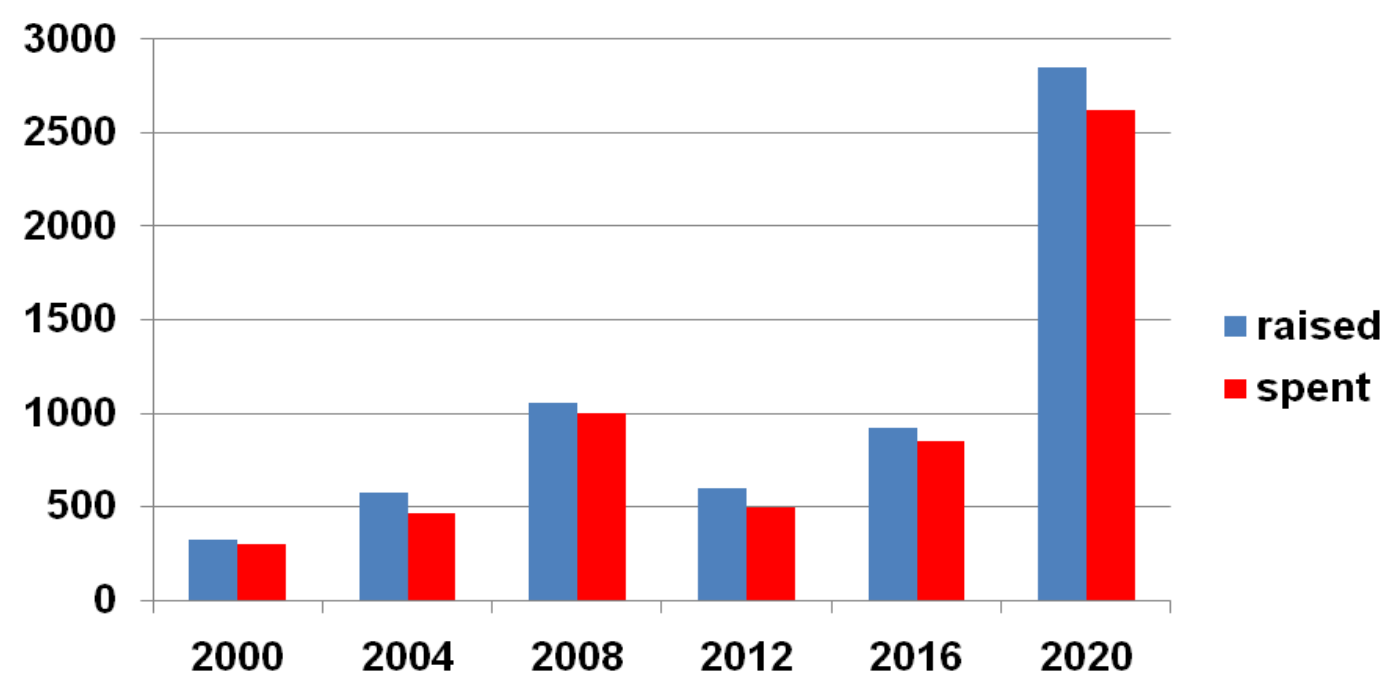

Source: compiled by the Author from Federal Election Commission (FEC) website.

\footnotetext{
${ }^{4}$ All data presented in figures and tables are in millions of nominal dollars.
} 


\section{Maciej Turek}

\section{Money in 2016 Presidential Nominations}

Both major party presidential nominees of 2016 would be expected to be money primary winners. Hillary Clinton had a long history of public service, becoming an instant frontrunner and poll leader after announcing her presidential bid. In addition to $100 \%$ name identification, long affiliation with the Democratic Party and experience of running campaigns on state and national level, Clinton had long been thought of "having the best political operation maybe in the history of the Democratic Party" (The Institute of Politics 2009: 34). All the above shall translate into coffers full of campaign cash.

The opposite, at least on the political experience and party support dimension, might be said of Donald Trump, who had never held a public office before running for a Republican nomination. Yet he had also had a household name, and proceeded with building his campaign image on being a successful businessman. At the time of his candidacy announcement, Trump was also personally richest - or at least was trying to persuade the world about that - candidate in a field. Therefore, the New York-based real estate magnate and celebrity, Trump was expected to self-fund his campaign effort, following the paths of Ross Perot and Steve Forbes, presidential hopefuls in last decade of the twentieth century. On the surface, the latter instance might have served as model for Trump, even though Forbes was neither leader in fundraising nor spending in his 1996 run. However, as of December 1995, he collected \$18 million in total, second to only Bob Dole, eventual Republican nominee (FEC 1996). Yet Forbes was not even close to Trump in terms of public support, as the future nominee and then president was already leading polls as early as in July 20, 2015. With exception of a brief period in November of 2015 (RealClearPolitics 2016), Trump was a frontrunner until collecting a required number of delegates to become a presumptive Republican nominee. In addition, due to his celebrity status Trump was widely recognized, and those two factors combined contributed to high volume of media exposure. All the above have traditionally been a key to successful fundraising campaign (Damore 1997; Goff 2004), and personal wealth would also position Donald Trump well in the money primary.

As data presented in figures 2 and 3 indicates, however, money can only partially explain the 2016 major party presidential nomination results. While Hillary Clinton fundraising summaries made her a clear winner of the money primary, at least as of end of December 2015, 
there was a different scenario for Donald Trump candidacy. Let me elaborate on both campaigns dynamics for a more thorough understanding of those two nomination races.

Despite his wealth, polling support and media exposure, Donald Trump was not the best positioned contender from the campaign finance point of view. Comparing six best-funded candidates in the Republican race - that of Ted Cruz, Ben Carson, Marco Rubio, Jeb Bush, John Kasich and the eventual nominee himself - the FEC data demonstrates that Trump started topping the field in both raising and spending for a single reporting period in March 2016 (FEC 2016c), a month at the end of which he had only two opponents effectively competing for the nomination (Turek 2017: 182). Considering models explaining success in major party presidential nomination, the low standing of Donald Trump in the money primary might be surprising. What is also worth emphasizing is the fact that in terms of cumulative fundraising, Trump committee raised the top among Republican Party nomination candidates as late as at the end of July 2016, long after the GOP race had been concluded.

Figure 2: Candidates' Receipts in the Primary Season by Reporting Periods, 2016 Democratic Party Nomination Campaign

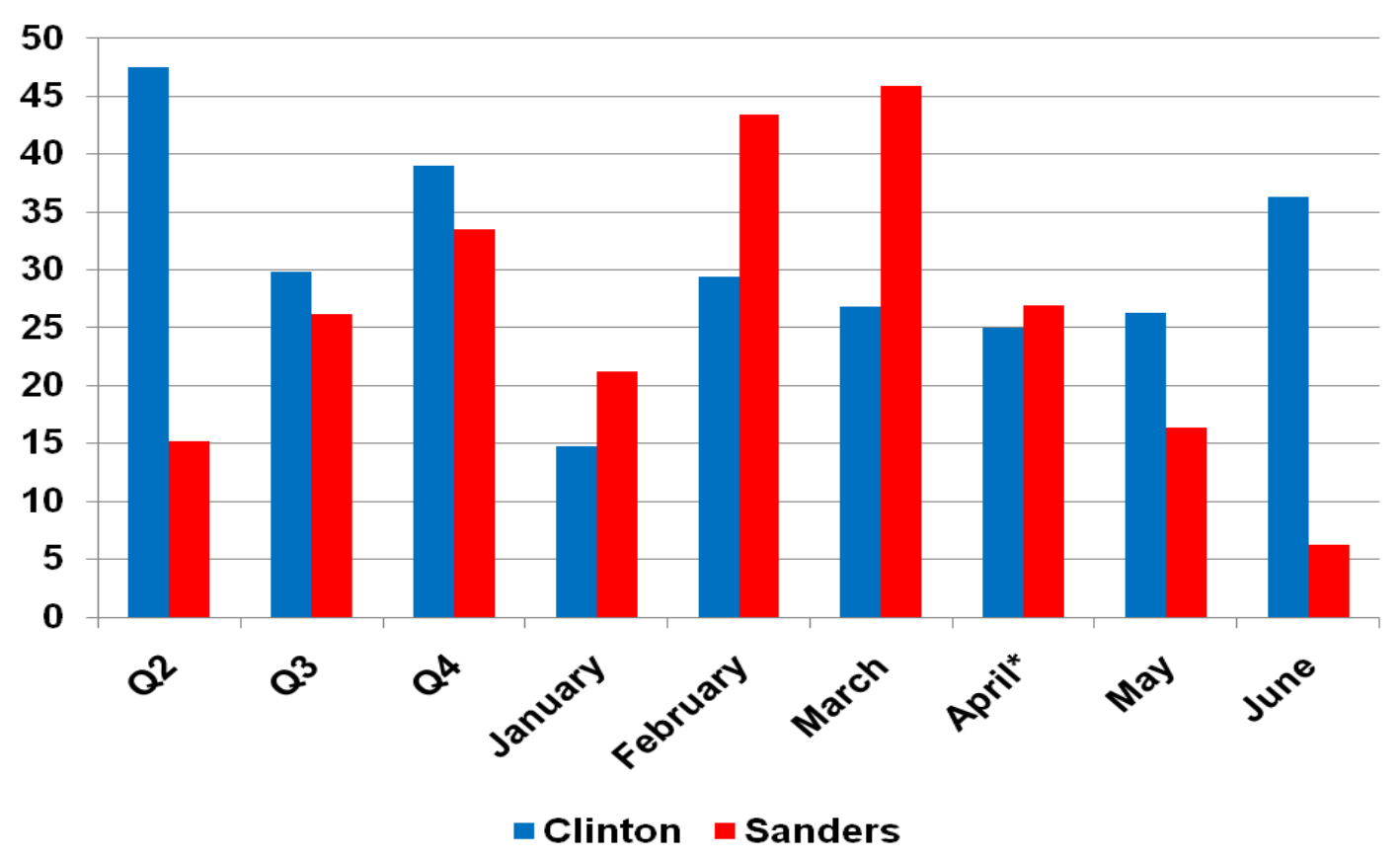

Source: FEC (2016a). 
Figure 3: Candidates' Cumulative Receipts in the Primary Season, 2016 Republican Party Nomination Campaign

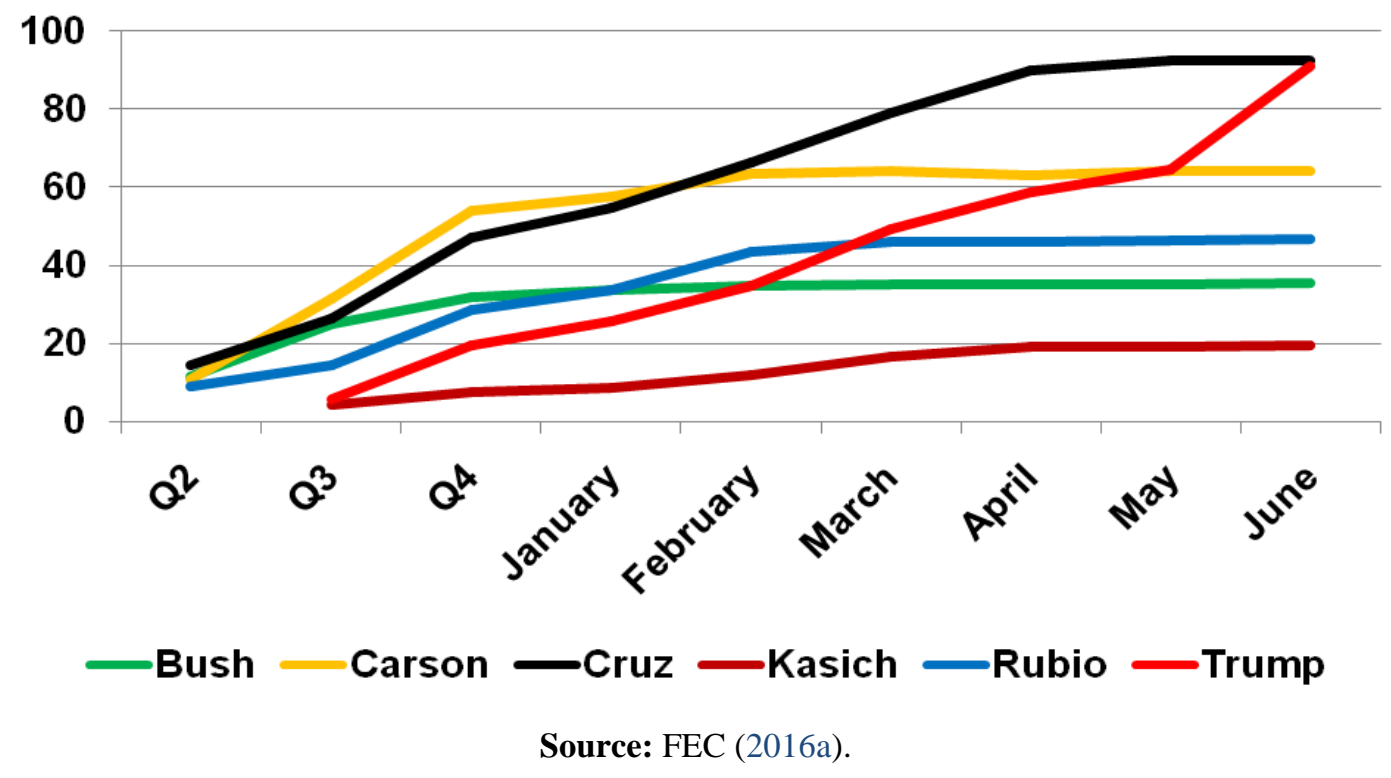

By defeating well-financed field of candidates, Trump managed to raise serious doubt about one of the long-lasting views of presidential nomination campaigns: that in order to be successful candidate for nomination, an individual shall be a top financial contender. Figure 3 clearly indicates that for the most part of the nomination race, Trump was very much behind his main rivals in terms of financial resources. The money primary is described by Goff (2004: 1) as "a critical period in defining the field of viable candidates that emerges before the primary and caucus process begins", whereas Adkins and Dowdle (2002: 257) understand is as "the competition of candidates for financial resources contributed by the partisan elites before the primaries begin". According to them, this race concludes with the finish of the exhibition season and start of the voting period in the nomination year, which constitutes the "operational year of the money primary" (Adkins \& Dowdle 2002: 264).

Trump also was not a top contender in terms of cash reserves (FEC 2016a). And considering he was neither beneficiary of SuperPAC spending, which in instances of several candidates outspent their campaign committees, as demonstrated in Table 1, it creates some kind of a puzzle in terms of money being essential for electoral success. It had been observed in the past that while "money cannot buy the nomination, (...) without the means to compete, no candidate, however meritorious, has a realistic chance of winning the nomination" (Steger 2000: 747) and that "candidates who are unable to raise significant resources, will be quickly winnowed 
out either before or during the early primaries and caucuses" (Adkins \& Dowdle 2000: 256). Robert Farmer, who was involved in campaigns of Michael Dukakis and Bill Clinton, went even further, claiming that "people don't lose campaigns. The run out of money and can't get their planes in the air. That's the reality" (Brown, Powell \& Wilcox 2003: 1). So how did Donald Trump actually won?

Table 1: Candidates' committees and SuperPAC spending in 2016 Republican Nomination Campaign, in million of nominal dollars

\begin{tabular}{lcc}
\hline & Campaign committee & SuperPAC \\
\hline Donald Trump & 64,6 & 2,0 \\
Ted Cruz & & \\
Ben Carson & 92,9 & 64,5 \\
Marco Rubio & 64,4 & 12,5 \\
Jeb Bush & 47,5 & 59,8 \\
John Kasich & 35,4 & 118,2 \\
Carly Fiorina & 19,5 & 25,8 \\
Scott Walker & 12,1 & 14,3 \\
Chris Christie & 8,8 & 24,1 \\
& 8,7 & 20,2 \\
\hline
\end{tabular}

Source: Green (2019: 139, 149).

The answer might be the allocation of resources. When Wayne Steger claimed that the nomination cannot be bought, he quickly added that without it candidates "cannot gain the exposure needed to attract supporters" (Steger 2000: 747). In one of his papers he went beyond finances, arguing that "only candidates who achieve sufficient recognition, resources and support are able to compete in the primaries" (Steger 2008: 194). While Trump built a considerable voter support even if his opponents had more the resources, in terms of recognition he was unbeatable. Data on presidential campaigns expenditures consistently shows that candidates spend heavily on salaries, travel and media, mainly air time and ad production. For nomination hopefuls who are not known by the voters, getting on television is the only way to gain awareness and present their cause. As Center for Responsive Politics data on spending in the 2016 Republican nomination contest depicts, of five of Trump's biggest opponents, only Jeb Bush media spending was not his biggest overall campaign spending share. At the same time, Ted Cruz, Marco Rubio, John Kasich and Ben Carson media spending constituted 31,3\%, on average of their total campaign committee disbursements (Center for Responsive Politics 2016). But Donald Trump, having a 100\% name identification among American citizens, did not have to worry about this. More importantly, he received a lot of media exposure he did not spend a dollar on. Scholars and campaign 


\section{Maciej Turek}

practitioners distinguish between paid media and free media. The former is the air time candidate has to pay to see their ads running on selected TV and radio stations. On the opposite site is the free media - the coverage candidate receives without paying for. It usually occurs when candidate does something spectacular, in either positive or negative way, that the media themselves find it interesting, worth covering and carry candidate name without candidates paying for air time.

Examining campaign coverage in eight television and press outlets during the time of invisible primary, Thomas Patterson found that Trump received the highest ad-equivalent value exposure among the GOP contenders (Patterson 2016b: 6), even though he spent on media much less than his rivals. In fact, "Trump did not start running media ads until January 2016" (Hershey 2017: 119). Yet his "controversial demeanor, expressive even if insulting comments on his rivals and even whole social groups, along with emotional statements published in social media" (Turek 2017: 250) demonstrated Trump mastery in getting attention which allowed him to "become his own media outlet" (Hershey 2017: 116). As Trump became content-creating machine, it made editors eager to run some juicy comment or exchange, apparently hoping to increase TV ratings and translate it into advertising income. Its growth even spurred Les Moonves, then-CEO of CBS Corporation, to comment that "Trump's presidential run may not be good for America, but it's damn good for CBS" (Weprin 2016). To illustrate Trump's media coverage advantage over his opponents, the New York Times reported on the media exposure of Trump and other major candidates for Republican nomination, as calculated by the company MediaQuant. The results, depicted in Table 2, show that spending only $\$ 10$ million by campaign committee and outside groups from the day of announcing candidacy throughout February 2016, Trump received free media coverage of almost $\$ 1.9$ billion (Confessore \& Yourish 2016), which could not be matched.

Table 2:Paid and Free Media Values of the Six Contenders of 2016 Republican Party Nomination Campaign, as of end of February 2016

\begin{tabular}{lrr}
\hline \multirow{2}{*}{ Candidate } & \multicolumn{2}{c}{ Media Exposure } \\
\hline Jeb Bush & Paid media & Free media \\
Ben Carson & 82 & 214 \\
Ted Cruz & 5 & 112 \\
John Kasich & 22 & 313 \\
Marco Rubio & 14 & 38 \\
Donald Trump & 55 & 204 \\
\hline
\end{tabular}

Source: Confessore \& Yourish (2016). 
All in all, in the 2016 Republican nomination race Donald Trump demonstrated that vast financial resources are not necessary to become major party presidential nominee. If a candidate is able to get media attention and turn it into support in both polls and voting booths, money is not that necessary as it was thought, at least was not in the 2016 cycle. One more important financial aspect of the Trump candidacy was that the candidate himself was the major source of campaign contributions. Of $\$ 64.6$ million the Donald J. Trump for President, Inc., his principal campaign committee raised through May 31, 2016, about 71\% came from the candidate either as direct contributions $(\$ 395,508)$ or loans $(\$ 45.7$ million) (FEC 2016c). He thus became the first modern-time major party presidential nominee to keep a nomination campaign afloat almost out his own pocket.

On the opposite, the campaign for 2016 Democratic Party nomination seems to be more conventional in terms of explaining the results through money variable. Although its financial aspects were not as nuanced as in the GOP case, it does not mean it was uninteresting. As of September 30, 2015, Hillary Clinton principal campaign committee raised more than other four Democratic contenders combined (FEC 2016a). Moreover, Clinton-aligned SuperPAC, Priorities USA Action, also had the highest amount of money at its disposal of all outside groups, willing to spend in Democratic race (Green 2019: 149). Thus from the organizational perspective, Clinton should have an open way to clinch the nomination quickly. It was also predicted by her campaign advisers, who were trying to create so called aura of inevitability - perception that the candidate will be the nominee, and neither internal circumstances nor other candidates can stop it. Scholars often theorize about two paradigms of presidential nomination campaign: organizationdriven and campaign-driven. On campaign finance perspective, the latter "ties its success to performance in campaign itself, often in the form of momentum; and an organization-driven model (...) ties the fundraising to the quality of candidates' political bases and fundraising efforts" (Hinckley \& Green 1996: 693). In other words, in the latter model campaigns raise more money due to its organizational advantage during the exhibition season, before voters go the polls. In campaign-driven model, candidates fundraising prosperity depends on how well they do in the subsequent caucuses and primaries. Out of about $\$ 467$ million raised by the two major candidates until end of May 2016 , 48,5\% was collected before voters went into polls, and 51,5\% after

\footnotetext{
${ }^{5}$ Although Clinton secured her nomination on June 7, I am using money raised until May 31, as those donating to both candidates from June 1 on, possibly contributed having general election support already in their minds.
} 


\section{Maciej Turek}

February 1. On individual level, Clinton raised 54,7\% during the exhibition season and 45,2\% from February through May.

Bernie Sanders fundraising, on the other hand, was more campaign-driven $(57,9 \%)$ than organization-driven (42\%). At the end of June 2015, Clinton reported raising more than three times as much as Sanders (FEC 2016a). But once the Vermont senator started introducing himself to the national electorate, he was getting attention in the media and his polling numbers were slowly growing. As presented in figure 2, Sanders managed to start a long march to reducing his fundraising distance to Clinton in each financial reporting period. In the third and fourth quarter of 2015, he raised $87 \%$ and $88 \%$ his rival. But from January through April 2016, Sanders collected much more than Clinton. If the former secretary of state figures are a reference point at 100, Sanders raised 143 in January, 147 in February, 171 in March, and 107 in April. In April, he also exceeded Clinton's total fundraising.

Meanwhile her SuperPAC, with constant cash balance of over $\$ 100$ million, was somehow useless because of the electoral context. During the nomination period, it spent only $\$ 5,63$ million in Clinton-supporting independent expenditures, without a single attack on Sanders (FEC 2016d). It was due to the fact that "Sanders made reforming of the campaign finance system one of the central points of his campaign. Accordingly, he did not endorse any of the SuperPACs, willing to support his candidacy. One might think that by doing so Sanders was unilaterally disarmed, as he deprived himself of using money if attacked by Clinton SuperPAC or her campaign. (...) Apparently, its management ceased spending more and against Sanders probably fearing that it would support his rhetoric against unlimited and outside money, painting Clinton as the candidate of interest groups and big money, not always supporting traditional Democratic causes" (Laidler \& Turek 2016: 321-322).

As an outsider candidate, Sanders also demonstrated the significance of a small donor, which was essential in gaining both the Democratic nomination and then presidency by Barack Obama. Campaign finance literature traditionally distinguishes between significant donors and small donors. The former are those contributing \$200 and more, while small donors are those who donate less. Throughout the campaign, Sanders was repeating that his campaign was not based on big money, as in case of Clinton, and as his standard stump speech never failed to mention that average contribution to his committee was $\$ 27$. As the data in Table 3 shows, Sanders candidacy was based indeed on contributions less than $\$ 200$ dollars. It constituted almost 
half of donations, whereas those donating $\$ 1000$ and more, accounted for only $17 \%$ of receipts of Bernie 2016 committee.

Table 3: Distribution of Individual Contributions to 2016 Democratic Nomination Campaign

\begin{tabular}{lcccc}
\hline Candidate & $\mathbf{< 2 0 0}$ & $\mathbf{\$ 2 0 1 - 9 9 9}$ & $\mathbf{\$ 1 0 0 0 - 2 6 9 9}$ & $\mathbf{\$ 2 7 0 0}$ \\
\hline Hillary Clinton & 33,0 & 29,9 & 16,3 & 20,8 \\
Bernie Sanders & 44,1 & 38,1 & 13,9 & 3,1 \\
\hline
\end{tabular}

Source: Green (2019: 144).

Unfortunately for Sanders, in neither reporting period the senator had an advantage in cash-on-hand reserves. Thus even if he was competitive candidate, he was unable to translate his financial assets and energy of his supporters, enthusiastic about Sanders candidacy, to beat Clinton. However, the explanation of Sanders' failure might not lie solely in the campaign finance, but more in shortcomings of his candidacy. Firstly, "his time in the U.S. Senate was not particularly distinguished" (Hetherington 2017: 66). More importantly from the perspective of his Democratic presidential run, he was actually not a member of the party (Turek 2018: 96), remaining independent. While he identified himself as a Democrat upon registering his presidential candidacy in 2016, he became a member of the party as late as in March 2019. It occurred as fulfillment of the Democratic National Committee condition, which before the start of 2020 presidential cycle "sought to clarify its membership requirements (...) by requiring every presidential candidate to sign the loyalty pledge" (Seitz-Weld 2019). Partisan independency was the reason that Sanders "was not very popular among congressional peers" (Hetherington 2017: 66) and clearly affected his ability to collect party endorsements during his first presidential run. As of May 31, 2016, Sanders' candidacy was supported by only 8 U.S. House of Representatives members and one senator, as Clinton was endorsed by 167 representatives, 21 senator and 15 state governors (Bycoffee 2015), demonstrating he was disconnected from the party's highest power echelons. Finally, Sanders never connected with Democratic most important voting groups, African Americans. As during the 2016 presidential cycle 87\% members of that group identified themselves as Democrats (Pew Research Center 2016: 8), it constituted 27\% of primary voters in the party nomination race (Mayer 2017: 44). Considering Sanders won only one in five voters in this segment of the electorate (Mayer 2017: 44), it was not only financial advantage that led to Hillary Clinton nomination. 
But does that mean that almost $\$ 220$ million, spent by Sanders campaign by May 31, 2016 (FEC 2016a), was all for nothing? Not at all. Winning primaries in ten states, and caucuses in another twelve, and amassing 13,2 million voters (Mayer 2017: 13) allowed Sanders supporters to become powerful coalition within the Democratic Party. Thus Sanders was not only able to shape the party platform before the 2016 general election (Turek 2018: 98), but also managed to push one of the most significant procedural change in the Democratic Party nomination rules in decades, limiting the role of automatic delegates, or superdelegates, at the national party convention (Democratic Party of the United States 2019). The financial network built during his 2016 candidacy also allowed Sanders to gain national recognition and play a role of a fierce critic of Donald Trump administration. On the electoral level, Sanders endorsed, with mixed results, several individuals who shared his progressive position on policy issues and were running for federal and statewide offices. While few believed he would seek presidency again, Sanders' capital from the previous campaigns, if applied again the presidential race, could have instantly put him in the top tier of candidates.

\section{Financing in the 2020 Democratic Presidential Nomination Campaign}

Dynamics of any political campaign is always determined by, among others, the electoral context, the number of candidates and their skills on the campaign trail. Who is running, particularly in the multicandidate field of the presidential hopefuls, also affects race's financial aspects. In case of 2020 Democratic campaign, there were three candidates who might have been equally expected to lead the money primary at the crucial date, end of December 2019.

When in February 2019 senator Bernie Sanders announced his second presidential bid, it was wondered whether he would recreate his impressive campaign organization in a multicandidate race. As again he was the only candidate whose policy proposals would situate him on the left of ideological spectrum of Democratic Party, Sanders was well positioned to persuade contributors, particularly small donors sympathizing with this fraction, to fill his coffers. Interestingly, being the top financial contender would also be anticipated from Joe Biden, the 2020 Democratic nominee. For this veteran politician, former six-term senator and vice president, it was third presidential nomination bid. He was rumored to run in the previous cycle, but in 2016 Biden abandoned the idea due to personal reasons. But once he entered the 2020 race on April 25, 2019, he became an instant frontrunner. Not only did he hold poll command through 
the whole period of exhibition season, as indicated in Figure 4. Before the voting started, Joe Biden also received the highest number of endorsements from local, state, and national party leaders (FiveThirtyEight.com 2020). As Marty Cohen and colleagues demonstrated (Cohen et al. 2008), endorsements in presidential nomination process are crucial in invisible primary period, as they help candidate built campaign organization, generate early voter support and raise money. Finally, the speculations that Michael Bloomberg might launch presidential campaign started when he "re-registered as a Democrat in 2018, having left the party in 2001 to register as a Republican" (Morin 2019). Thus when Bloomberg indeed announced his candidacy in November 2019, it was actually a matter of time when the billionaire, the ninth richest man in the world according to Forbes 2019 list, would become a leader of the money race.

If not for Bloomberg, who in the end had virtually no influence on the nomination results, the validity of the Mayer model for the 2020 Democratic Party nomination would depend on whether it was Bernie Sanders or Joe Biden to raise most money. Had the small donor model been more significant in allocating financial resources, as it was in the 2008 campaign of Barack Obama, Sanders would have prevailed. But had the party model (Cohen et al. 2008) dominated, Biden would be destined to raise the most. The issue was whether money influence would follow 2016 Democratic or Republican nomination path.

When Sanders campaign revealed their financial reports, the senator was clearly satisfied. As indicated in Figure 5, Sanders was a fundraising leader - with the exception of self-funded candidacies of billionaires Michael Bloomberg and Tom Steyer, both of whom never received voter appeal - throughout the whole campaign. Particularly important for the campaign setting, however, was the reporting period after the second quarter of 2019. The conventional wisdom is that field of candidates for party nomination is usually shaped until end of June of pre-election year. This was the case in the 2020, as the top vote getters entered the race between February and April of 2019. 
Figure 4: 2020 Democratic Party Nomination Polls Standing, May 1, 2019-January 31, 2020

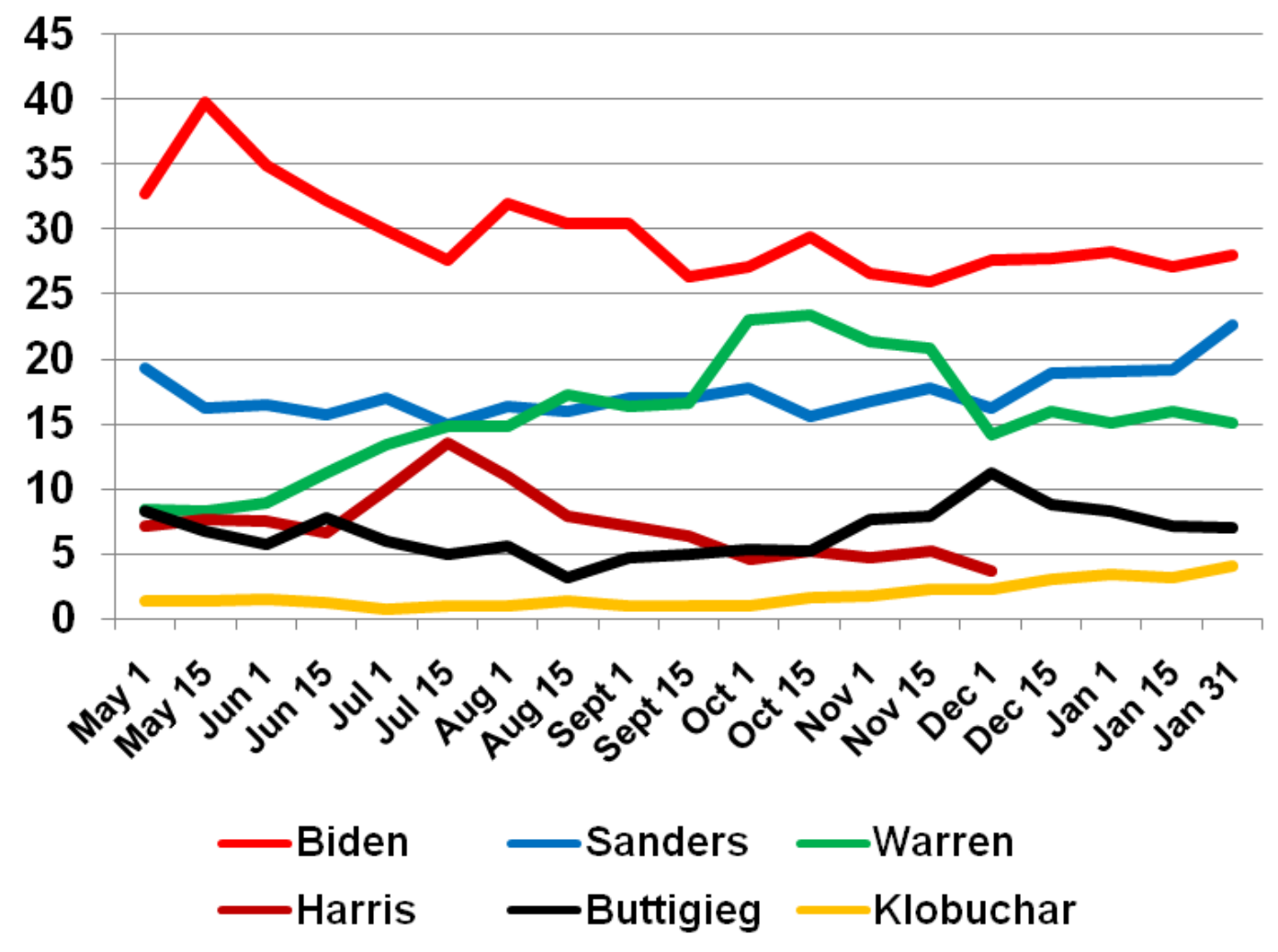

Source: RealClearPolitics.com (2020).

Figure 5: Candidates' Cumulative Receipts in the Primary Season, 2020 Democratic Party Nomination Campaign

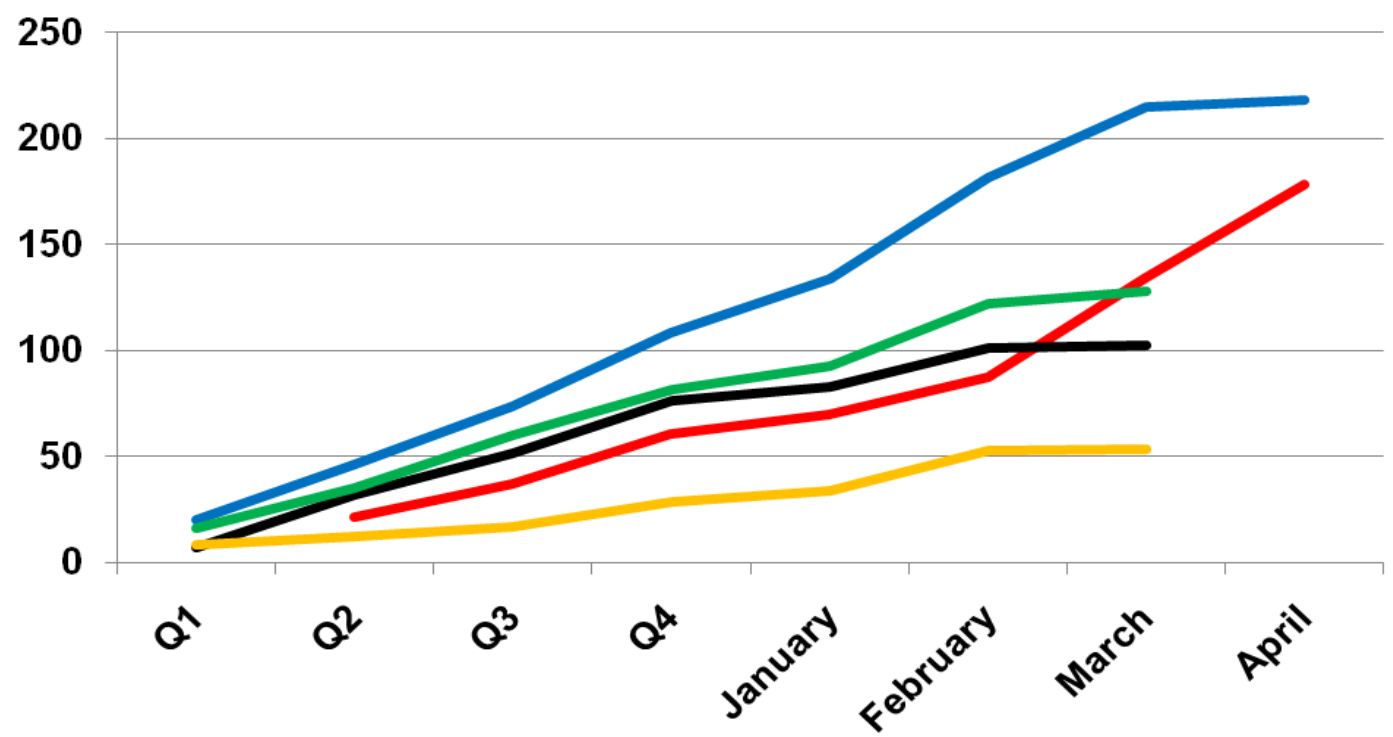

-Biden -Buttigieg - Klobuchar - Sanders - Warren

Source: compiled by the Author from Federal Election Commission (FEC) website. 
At the end of June 2019, Sanders campaign raised \$46 million, trailing senator Elizabeth Warren (\$35 million), South Bend mayor and novice on national political stage Pete Buttigieg (\$32 million), senator Kamala Harris (\$25 million), but most importantly, Joe Biden (\$22 million) (FEC 2019). Within Sanders campaign circles, it was thought that the fundraising difference would translate into building support for the senator and slip for Biden closer to the voting phase of the primary season. This scenario briefly materialized following first three contests, when Sanders took the polling lead after winning New Hampshire primary and Nevada caucus whereas lost Iowa caucus by just $0,1 \%$ of votes.

Figure 6: 2020 Democratic Party Nomination Polls Standing, February 1-April 8, 2020

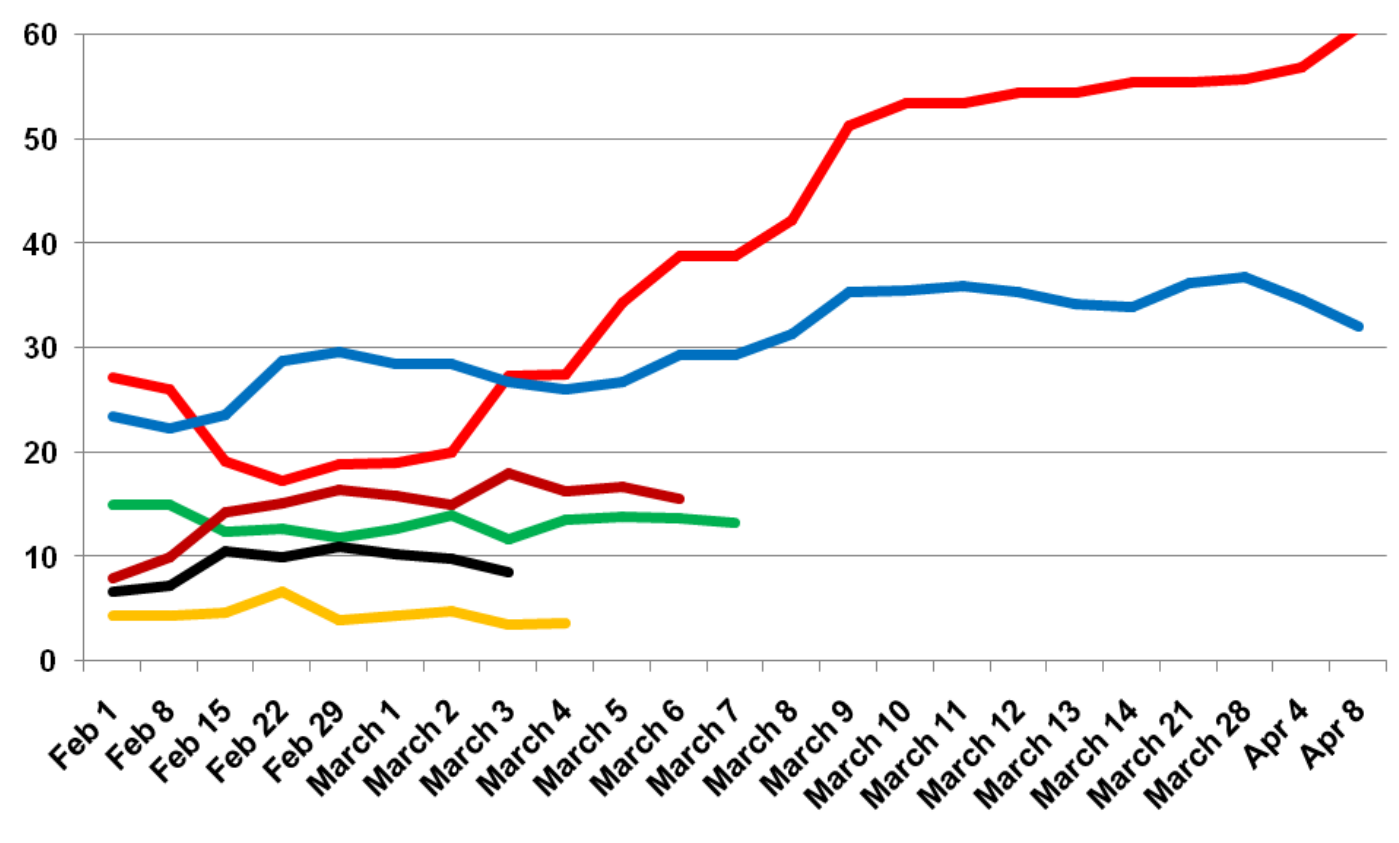

—Biden — Sanders — Warren —Buttigieg Klobuchar —Bloomberg

Source: RealClearPolitics.com (2020).

But the conclusion of the 2020 Democratic nomination race again demonstrated the limits of money in presidential election politics. While the results of the initial contests were successful for Sanders and his financial advantage was also substantial, he was never able to amass national support of more than $30 \%$ of the Democratic electorate, as long as the nomination race was still multicandidate. In February, after a setback in appeal in early voting states, many started writing Joe Biden political obituaries, he showed that in nomination politics building a strong coalition 


\section{Maciej Turek}

can be more important than other resources. Presenting the phenomenon of winnowing, Steven Brams (2008: 13) argued that in a nomination race "first-priority goal is not be eliminated. In a multicandidate race, this goal often translates into not being defeated by an opponent or opponents who appeal to the same segment of party electorate". Thus from the perspective of Biden success, it was important that following the initial contests, his failing position did not substantially strengthen the other moderates in the race, Pete Buttigieg and Amy Klobuchar. At the same time, as long as Elizabeth Warren, Sander's closest on ideological level, was actively campaigning, the Vermont senator was unable to gain advantage over the rest of the field that would make his candidacy unstoppable.

Did Biden need a lot of money to turn the race around? Not necessarily. In February and March, when the race was effectively decided, Biden campaign spent $\$ 45,5$ million, less than Sanders committee in February alone. In addition, outside money were almost non-existent in the Democratic race. As of March 31, 2020, only about \$12,5 million was spent on behalf of Biden (FEC 2020a), which main SuperPAC, Unite the Country ceased from attacking senator Sanders. Major source of Biden win was, tough, not money, but support of party officials, moderate voters and those who were afraid that Sanders nomination might pave the way to reelection of Donald Trump. Once former vice president decidedly won South Carolina primary, Pete Buttigieg and Amy Klobuchar, with only minor chances for the nomination clinch, ended their campaigns immediately endorsing Biden. Becoming the only moderate in the race allowed him to consolidate broad coalition behind him, leading to win in 16 contents (out of 22) on March 3 and week later. In the meantime, Elizabeth Warren and Michael Bloomberg left the race, which, along limited opportunities for ground campaigning and organizing rallies due to COVID-19, made Biden unstoppable. Despite spending considerably more than Biden - \$203 million versus \$108 million at the end of March 2020 (FEC 2020b) - Bernie Sanders suspended his campaign on April 8, effectively handing Democratic nomination to Biden.

\section{Billionaire Candidates in the 2020 Presidential Nomination Campaign}

The financial story of the 2020 Democratic nomination could not be fully told without mentioning activities of self-funded candidates, Michael Bloomberg and Tom Steyer. Although both were coined as billionaire candidates, they were involved in Democratic Party politics 
before. Between 2002 and 2013 Bloomberg was a mayor of New York, the office he won as Republican, but turned Independent in 2007. Yet from 2010 on, he contributed about $\$ 162$ million to outside groups, who helped elect Democratic candidates in independent expenditures (Center for Responsive Politics 2020). Former hedge fund manager Tom Steyer donated ever more, \$284 million, between 2014 and 2020 (Center for Responsive Politics 2020a). Considering that at 63 he is relatively young comparing to recent American electioneering standards, it is conceivable that he will be seen again on the presidential campaign trail. Both Steyer and Bloomberg entered the 2020 Democratic race relatively late, in July and November, respectively. Yet once they did, they were immediate spending leaders. While Steyer spent $\$ 47$ million in the third quarter (FEC 2020d), more than double than Bernie Sanders, the billionaires smashed the rest of the field in the final quarter of 2019, with Bloomberg assigning \$188 million and Steyer $\$ 153$ million. Altogether, at the end of the month their campaigns concluded, Steyer spent \$344 million as of February 29 (FEC 2020d; 2020e). Bloomberg became first candidate to exceed a billion dollars in presidential nomination campaign expenditures, spending $\$ 1,051$ billion as of March 31 (FEC 2020a). Both candidates were involved in massive media buying, as it accounted for 76\% (Steyer) and 68\% (Bloomberg) of overall campaign spending (Center for Responsive Politics 2020b; 2020c). Was it worth it? Well, if Steyer will play vital role in Democratic Party politics in the future, he will surely point to the 2020 race as a step toward building name identification, base support and networking among campaign professional and advisers. But from the vote and delegate-getting perspectives, gains of both candidates were rather unimpressive. Steyer came distant seven, six and five in first three contests, receiving $11,7 \%$ votes in South Carolina, after which he suspended his campaign without a single pledged delegate gain. When it comes to Bloomberg, his campaign activities seem to be more influential even if short-lived. As seen at Figure 6, he started polling at about $10 \%$ on February 5, to overtake Elizabeth Warren a week later. While he gained little or none support in first fours contests, Bloomberg received handful of votes on Super Tuesday on February 3, winning American Samoa caucus, and even was awarded 44 convention delegates. It certainly did not satisfy the candidate, as he dropped from the race the very next day.

What is also worth mentioning is the fact that these candidates financed their campaign activities from their owned pockets. As of March 31, Steyer received only \$3,7 million in 


\section{Maciej Turek}

contributions from individuals (FEC 2020d), while Bloomberg even less, \$916 thousands to be exact (FEC 2020e). In both cases, however, this money was all for nothing, at least as of 2020 Democratic presidential nomination process.

\section{Conclusion}

Is money important in contemporary presidential nomination politics? It is. The candidates need resources to pay salaries to their campaign advisers and workers, for media and ground advertising, for travel and various administrative expenses. Without a considerable war chest it is not possible to effectively operate in a very competitive multicandidate field for several months of a primary campaign. But is money the most important factor explaining the final results of presidential nominations? Not necessarily. While it seemed to be a crucial factor between 1980 and 2000, when candidates who raised the most at the end of pre-election year won in almost all instances, from the 2004 cycle on it happened only twice. At the same time, Mitt Romney in 2012 and Hillary Clinton in 2016 had the support of partisan establishment and were leading public opinion polls throughout the whole (Clinton) or predominating period (Romney) of the nomination process. While in 2020 Joe Biden was overwhelmed financially by several candidates, not mentioning Michael Bloomberg and Tom Steyer, his decisive resource seemed to be diversity of party endorsements and support from various groups. They did not abandon him when his candidacy was down after poor showings in initial nomination contests. This bond, in the making through the years of partisan activity of the former vice president, was something that money of Bloombergs, Steyers, and even Bernie Sanders could not buy.

From the outset, explaining 2016 successful nomination of Donald Trump seems to be the hardest task, as he did have neither campaign money nor party establishment support. His biggest asset, however, was the skill of dominating communication channels in traditional, social and digital media. Trump received highest media exposure without having to pay for the air time, winning the attention of Republican primary voters. Equally important was the fact that despite stable and solid polls standings, his candidacy was underestimated by nomination opponents. As longtime Republican campaign operative Stuart Stevens observed, "Donald Trump consistently benefited from the inability to imagine him winning. That belief shaped the Republican primary. (...) So the real race was to beat every candidate whose last name wasn't Trump, and then the last 
stage, just beating Trump, would be an easy layup" (Stevens 2020: 149). In other words, "the field of nomination hopefuls almost ignored Trump - neither attacking him personally nor questioning his policy proposals. When after the initial contests it turned out Trump was able to translate polling numbers into votes, it was too late" (Turek 2017: 177). All the better funded campaigns of Ted Cruz, Marco Rubio or Ben Carson could not stop the tide.

Thus, while a few dozens of millions of dollars is still required for a nomination success, raising and spending more than the rest of field is not a precondition to win. As the two recent electoral cycles clearly demonstrated, nomination hopefuls might consider spending less time courting donors and more building coalitions. In the long term, it shall pay bigger dividends than spending hundreds of millions or even billion dollars, on a campaign effort.

\section{References:}

Adkins, R. E., \& Dowdle, A. J. (2000). Break Out the Mint Juleps? Is New Hampshire the "Primary" Culprit Limiting Presidential Nomination Forecasts?. American Politics Quarterly, 28(2), 251-269.

Adkins, R. E., \& Dowdle, A. J. (2002). The Money Primary: What Influences the Outcome of Pre-Primary Presidential Nomination Fundraising?. Presidential Studies Quarterly, 32(2), 256-275.

Adkins, R. E., \& Dowdle, A. J. (2005). Do Early Birds Get the Worm? Improving Timeliness of Presidential Nomination Forecasts. Presidential Studies Quarterly, 35(4), 646-660.

Brams, S. J. (2008). The Presidential Election Game. Wellesley: A. K. Peters.

Brown, C. W., Jr., Powell, L. W., \& Wilcox, C. (1995). Serious Money: Fundraising and Contributing in Presidential Nomination Campaigns. New York: Cambridge University Press.

Bycoffee, A. (2016). The Endorsement Primary. https://projects.fivethirtyeight.com/2016-endorsement-primary/ $(21 / 07 / 2017)$.

Center for Responsive Politics. (2016). Also-Rans: 2016 Presidential Race.https://www.opensecrets.org/pres16/alsorans $(23 / 08 / 2010)$.

Center for Responsive Politics. (2020a). Top Donors to Outside Spending Groups, 2010-2020.

https://www.opensecrets.org/outsidespending/summ.php (23/08/2020).

Center for Responsive Politics. (2020b). Expenditures Breakdown, Tom Steyer, 2020 cycle.

https://www.opensecrets.org/2020-presidential-race/expenditures/tom-steyer?id=N00044966 (23.08.2020).

Center for Responsive Politics. (2020c). Expenditures Breakdown, Michel Bloomberg, 2020 cycle. https://www.opensecrets.org/2020-presidential-race/expenditures/michael-bloomberg?id=N00029349 (23/08/2020).

Cohen, M., David, K., Noel, H., \& Zaller, J. (2008). The Party Decides: Presidential Nominations before and after Reform. Chicago: Chicago University Press.

Confessore, N., \& Yourish, K. (2016), \$2Billion Worth of Free Media for Donald Trump. The New York Times, 15.03 .

Damore, D.F. (1997). A Dynamic Model of Candidate Fundraising: The Case of Presidential Nomination Campaigns. Political Research Quarterly, 50(2), 343-364. 


\section{Maciej Turek}

Democratic Party of the United States (2019). Call for the 2020 Democratic National Convention. https://democrats.org/wp-content/uploads/2019/02/2020-Call-for-Convention-WITH-Attachments-2.26.19.pdf $(21 / 08 / 2020)$.

FEC (1996). Presidential Receipts through Deember 31, 1995. https://www.fec.gov/resources/campaign-financestatistics/1996/tables/presidential/Pres1_1995_12m.pdf (15/06/2020).

FEC (2016a). Presidential Campaign Finance Summaries. https://www.fec.gov/campaign-finance-data/presidentialcampaign-finance-summaries/ (15/06/2020).

FEC (2016b). Presidential Pre-Nomination Campaign Disbursements May 31, 2016.

https://transition.fec.gov/press/summaries/2016/tables/presidential/presdisbursements_2016_m6.pdf (15/06/2020).

FEC (2016c). Donald Trump for President, Inc. Committee fillings, 2015-2016.

https://www.fec.gov/data/committee/C00580100/?tab=filings\&cycle=2016 (15/06/2020).

FEC (2016d). Priorities USA Action, Independent Expenditures, 2015-2016.

https://www.fec.gov/data/committee/C00495861/?cycle=2016\&tab=spending\#independent-expenditures $(15 / 06 / 2020)$.

FEC (2019). Presidential Pre-Nomination Campaign Receipts Through June 30, 2019.

https://transition.fec.gov/press/summaries/2020/tables/presidential/PresCand1_2019_6m.pdf (15/06/2020).

FEC (2020a). Independent Expenditures Made For or Against 2020 Presidential Candidates Through March 31, 2020. https://transition.fec.gov/press/summaries/2020/tables/ie/IE2_2020_15m.pdf (15/06/2020).

FEC (2020b). Presidential Pre-Nomination Campaign Disbursements Through March 31, 2020. https://transition.fec.gov/press/summaries/2020/tables/presidential/PresCand2_2020_15m.pdf (15/06/2020).

FEC (2020c). Presidential Pre-Nomination Campaign Disbursements Through December 31, 2019. https://transition.fec.gov/press/summaries/2020/tables/presidential/PresCand2_2019_12m.pdf (15/06/2020).

FEC (2020d). Tom Steyer 2020 Committee fillings, https://www.fec.gov/data/committee/C00711614/?tab=filings $(23 / 08 / 2020)$.

FEC (2020e). Mike Bloomberg 2020, Inc. Committee fillings,

https://www.fec.gov/data/committee/C00728154/?cycle=2020 (23/08/2020).

FiveThirtyEight.com (2020). The 2020 Endorsement Primary. https://projects.fivethirtyeight.com/2020endorsements/democratic-primary/ (21/08/2020).

Goff, M. J. (2004). The Money Primary: the New Politics of the Early Presidential Nomination Process. Lanham: Rowman \& Littlefield.

Green J. C. (2019). Financing the 2008 Presidential Nomination Campaigns. In: D. G. Magleby, \& A. Corrado (eds.), Financing the 2016 Election (pp. 131-186). Washington, D.C.: Brookings Institution Press.

Green J. C., \& Kingsbury D. (2011). Financing the 2008 Presidential Nomination Campaigns. In: D. G. Magleby, \& A. Corrado (eds.), Financing the 2008 Election (pp. 86-126). Washington, D.C.: Brookings Institution Press.

Hershey, M. R. (2017). The Media. Covering Donald Trump. In: M. Nelson (ed.), The Elections of 2016 (pp. 113135). Thousand Oaks: CQ Press.

Hetherington, M. J. (2017). The Election. The Allure of the Outsider. In: M. Nelson (ed.), The Elections of 2016 (pp. 63-86). Thousand Oaks: CQ Press.

Hinckley, K. A., \& Green, J. C. (1996). Fund-Raising in Presidential Nomination Campaigns: The Primary Lessons of 1988. Political Research Quarterly, 49(4), 693-718.

Laidler, P., \& Turek, M. (2016). Cena demokracji. Finansowanie federalnych kampanii wyborczych w Stanach Zjednoczonych Ameryki. Kraków: Księgarnia Akademicka.

Malbin, M. J, \& Glavin, B. (2018). CFI's Guide to Money in Federal Elections. 2016 in Historical Context. http://www.cfinst.org/pdf/federal/2016Report/CFIGuide_MoneyinFederalElections.pdf (15/06/2020). 
Mayer, W. G. (1996). Forecasting Presidential Nominations. In: W. G. Mayer (ed). In Pursuit of the White House. How We Choose Our Presidential Nominees (pp. 44-71). Chatham: Chatham House Publishers Inc.

Mayer, W. G. (2003). Forecasting Presidential Nomination, or My Model Worked Just Fine, Thank You. PS: Political Science and Politics, 36(2), 153-157.

Mayer, W. G. (2009). Superdelegates: Reforming the Reforms Revisited. In: S. S. Smith, \& M. J. Springer (eds.). Reforming the Presidential Nomination Process (pp. 85-108). Washington D.C.: Brookings Institution Press.

Mayer, W. G. (2017). The Nominations. The Road to a Much-Disliked General Election. In: M. Nelson (ed.), The Elections of 2016 (pp. 29-62). Thousand Oaks: CQ Press.

Morin, R. (2019). Bloomberg: Independent presidential bid would 'end up re-electing Trump'. Politico.com. https://www.politico.com/story/2019/01/28/bloomberg-2020-elections-howard-schultz-1129214 (23/08/2020).

Patterson, T. E. (2016a). News Coverage of the 2016 Presidential Primaries: Horse Race Reporting Has Consequences. https://shorensteincenter.org/wp-content/uploads/2016/07/Election-2016-Primary-Media-

Coverage.pdf (20/05/2017).

Patterson, T. E. (2016b). Pre-Primary News Coverage of the 2016 Presidential Race: Trump's Rise, Sanders Emergence, Clinton's Struggle, https://shorensteincenter.org/wp-content/uploads/2016/06/Pre-Primary-NewsCoverage-Trump-Sanders-Clinton-2016.pdf (20/05/2017).

Pew Research Center. (2016). The Parties on the Eve of the 2016 Election: Two Coalitions, Moving Further Apart, https://www.pewresearch.org/politics/2016/09/13/the-parties-on-the-eve-of-the-2016-election-two-coalitionsmoving-further-apart/ (20/08/2020).

RealClearPolitics.com (2016). 2016 Republican Presidential Nomination Polls, https://www.realclearpolitics.com/epolls/2016/president/us/2016_republican_presidential_nomination-3823.html $(17 / 08 / 2020)$.

RealClearPolitics.com (2020). 2020 Democratic Presidential Nomination Polls, https://www.realclearpolitics.com/epolls/2020/president/us/2020_democratic_presidential_nomination-6730.html (17/08/2020).

Redlawsk, D. P., Tolbert, C. J., \& Donovan, T. (2011). Why Iowa? How Caucuses and Sequential Elections Improve the Presidential Nominating Process. Chicago and London: The University of Chicago Press.

Seitz-Weld, A. (2019). Bernie Sanders sings DNC loyalty pledge: 'I am a member of the Democratic Party, https://www.nbcnews.com/politics/2020-election/bernie-sanders-signs-dnc-loyalty-pledge-i-am-member-democraticn979696 (25/08/2020).

Steger, W. P. (2000). Do Primary Voters Draw from a Stacked Deck? Presidential Nominations in an Era of Candidate-Centered Campaigns. Presidential Studies Quarterly, 30(4), 727-753.

Steger, W. P. (2007). Who Wins Nomination and Why? An Updated Forecast of the Presidential Primary Vote. Political Research Quarterly, 60(1), 91-99.

Steger, W. P. (2008). Forecasting the Presidential Primary Vote: Viability, Ideology and Momentum. International Journal of Forecasting, 24(2): 193-208.

Stevens, S. (2020). It Was All a Lie. How the Republican Party Became Donald Trump, New York: Arthur A. Knopf.

The Institute of Politics (2009) Campaign for President. The Managers Look at 2008, Lanham: Rowman \& Littlefield.

Turek, M. (2013). Amerykański system finansowania wyborów i jego konsekwencje. In: P. Napierała, \& A. Małek (eds.), Stany Zjednoczone wczoraj $i$ dziś. Wybrane zagadnienia społeczno-polityczne (pp. 167-199). Kraków: Księgarnia Akademicka.

Turek, M. (2016). Krótka historia SuperPACs. In: P. Napierała,\& R. Kuś (eds.), Oblicza Ameryki. Szkice o spoleczeństwie, kulturze i polityce Stanów Zjednoczonych Ameryki (pp. 177-194). Kraków: Księgarnia Akademicka.

Turek, M. (2017). Prawybory prezydenckie w Stanach Zjednoczonych Ameryki. Bilans czterech dekad, 1976-2016. Kraków: Księgarnia Akademicka. 


\section{Maciej Turek}

Turek, M. (2018). Feel the Bern: prezydencka kandydatura Bernie'go Sandersa i jej dziedzictwo. In: Ł. Niewiński, (ed.), Czas wojny, czas pokoju. Stany Zjednoczone Ameryki od niepodległości do współczesności (pp. 86-103). Oświęcim: Napoleon V.

Weprin, A. (2016). CBS CEO Les Moonves clarifies Donald Trump 'good for CBS' comment. Politico.com. https://www.politico.com/blogs/on-media/2016/10/cbs-ceo-les-moonves-clarifies-donald-trump-good-for-cbscomment-229996 (20/07/2017).

Witcover, J. (1997). No Way to Pick a President. New York: Farrar, Straus and Giroux. 